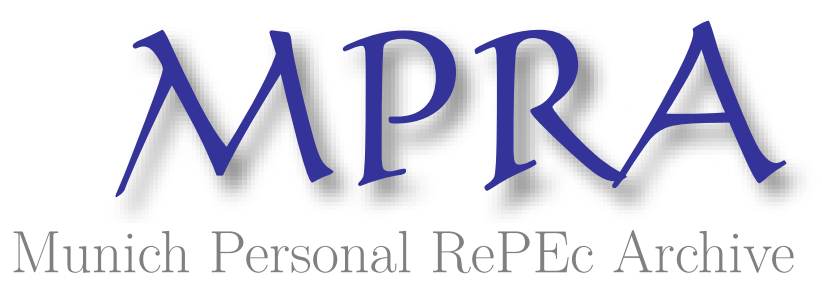

\title{
Rain, Rain, Go Away? The Investment Climate, State Business Relations and Firm Performance in India
}

Vinish, Kathuria and Seethamma Natarajan, Rajesh Raj and Sen, Kunal

23 January 2010

Online at https://mpra.ub.uni-muenchen.de/20316/

MPRA Paper No. 20316, posted 29 Jan 2010 13:36 UTC 


\title{
Rain, Rain, Go Away? The Investment Climate, State Business Relations and Firm Performance in India*
}

\author{
Vinish Kathuria ${ }^{\mathrm{a}}$, S. N. Rajesh Raj ${ }^{\mathrm{b}}$ and Kunal Sen ${ }^{\mathrm{c}}$
}

\begin{abstract}
:
It is commonly argued that a better investment climate reform - that is, lower distortions in the institutional, policy and regulatory environment in which firms operate - lead to discernible improvements in firm performance. In this paper, we argue that effective state business relations condition better investment climate outcomes and that the deeper institutional determinants of firm performance are the former. We examine the effect of effective state-business relations of total factor productivity (TFP) for formal sector firms in India for the years 2000-01 and 2004-05 and find support for this hypothesis.
\end{abstract}

Keywords: State business relations, total factor productivity, India.

\footnotetext{
* This paper forms a part of a larger study examining the effect of state-business relations on the productivity of Indian firms funded by IPPG-University of Manchester, UK (www.ippg.org.uk). We are thankful to IPPG-University of Manchester and DFID-UK for financial support. We are also thankful to the Central Statistical Organisation, for providing us access to the data, and to Nilachal Ray for his strong interest in the research and for his many suggestions and comments. The usual disclaimers apply.

${ }^{\text {a }}$ SJMSOM, Indian Institute of Technology Bombay, India

${ }^{\mathrm{b}}$ Centre for Multi-Disciplinary Development Research, Dharwad 580004, Karnataka, India

${ }^{\mathrm{c}}$ IDPM, University of Manchester, UK
} 


\section{INTRODUCTION}

One of the key tenets of the Washington Consensus view of economic policy making is that investment climate reform - that is improvements in 'the institutional, policy and regulatory environment in which firms operate ${ }^{1}$ - lead to discernible improvements in firm performance and consequently, an increase in economic growth. There has been a large empirical literature that is adduced to support the proposition that investment climate reform can lead to productivity improvements and higher economic growth. Several studies in this literature show that various indicators of a poor investment - such as power supply interruptions, high regulatory burden in the form of time firm management spend with government inspectors, corruption, and poor access to finance - have a negative effect on firm productivity and growth. ${ }^{2}$ Recommendations to reform the investment climate are now an indispensable component of the standard policy advice that World Bank and the IMF offer to developing countries.

The Washington Consensus proposition that investment climate reform can lead to higher productivity and overall growth has not been without its critics. There have been two main sets of criticisms levelled at the investment climate literature. Firstly, as Moore and Schmitz (2008, p. 10) argue, "the core conceptual problem with (the) orthodoxy is that government and political power are viewed primarily as persistent threats to capital, investment and economic growth. From that perspective, the policy mission is to curtail the influence of political power through formal rules, laws and institutions. If that mission fails, politicians are expected at least to maltreat the private economy, and possibly to loot it, and thus, undercut economic growth." Thus, there is a strong assumption in the literature that the state, by its very nature, is always predatory, and cannot be developmental in most instances of its manifestations. This is contrary to an alternate view that takes the position that 'good growth-enhancing relations between business and government elites are possible' (Maxfield and Schneider 1997, Harriss 2006). That collaborative state-business relations can be growth-enhancing has been reflected in a long-standing literature in political science and in political economy (e.g., Amsden 1989, Evans 1995).

\footnotetext{
${ }^{1}$ See Dollar et al., 2005, p. 1.

${ }^{2}$ For comprehensive surveys of the literature, see Dethier et al. (2008) and Commander and Trinn (2008).
} 
A second criticism of the investment climate literature is that it confuses cause and effect by focusing on the outcomes of effective state action, rather than the underlying structural factors that determine these outcomes (Carlin et al. 2008). Thus, better quality provision of electricity or lower corruption is more likely to occur when governments have a strong interest in promoting private sector development, and when they signal their commitment to the growth of the private sector via better public good provision and a lower degree of rent seeking activities. An important limitation of focusing on the outcomes of effective state action, rather than their determinants, is that very often, and particularly in recent years, there has been an improvement in investment climate indicators in many developing countries without a corresponding improvement in economic performance (Commander and Trinn 2008). We would argue that this is due to governments not being credible in their signalling to the private sector that they are really interested in the growth of the latter, or where new formal institutions have brought into place when the informal institutions are not complementary to these formal institutions (Steer and Sen 2008). As an opposite case, there have been instances of developing countries (such as China and Vietnam) where there has been a surge in private sector investment and growth without an ostensible improvement in investment climate measures (Moore and Scmitz 2008). This again in our view is due to the possibility that investors are more interested in the state's overall commitment to growth oriented outcomes, and that the latter may over-ride certain weaknesses in the investment climate such as insecurity of formal property rights and high degrees of corruption.

In this paper, we dig deeper into the determinants of better investment climate outcomes by focusing on their underlying causes, which we argue are effective state business relations. In our view, a synergistic relationship between the state and the business sector, which is based on strong and well organised states and private sector associations, is more likely to lead to the provision of public goods such as roads and electricity, and a lower regulatory burden on the private sector. In the next section, we argue why this is the case, and why effective state business relations may improve firm performance, and hence, overall economic welfare.

Our empirical context is India, which provides us a fertile empirical ground to examine the relationship between effective state business relations and economic 
performance at the micro level. ${ }^{3}$ Given India's federal political structure, we would expect to see wide variations in the manner Indian state governments interact with the business sector. Given the nature of economic reforms in India, which has been gradualist since their onset in the 1980s, and the political space these reforms provided to state governments to follow their own paths with specific economic policies (within certain constraints), we would expect significant time variation in effective state business relations across Indian states. ${ }^{4}$

The second advantage of using India as a case-study is the availability of firm-level data for the formal/organised sector. We have access to unit record data from the Annual Survey of Industries (ASI) for the formal sector for the years 2000-01 and 2004-05.

The rest of the paper is in six sections. In the next section, we set out the theoretical argument why effective state business relations matter for economic performance. In Section III, we describe the measure of state-business relations in India, drawing from the work of Cali, Mitra and Purohit (2009) (henceforth, CMP). Section IV describes the firm-level data and the methodology. In Section V, we discuss the results of our analysis. Section VI concludes.

\footnotetext{
${ }^{3}$ In the Indian case, a handful of studies have examined the relationship between investment climate and economic performance at the sub-national level using firm or industry data (Dollar et al., 2002; Veermani and Goldar, 2004; and World Bank, 2004). These studies find that states with better investment climate plays a significant role in productivity growth.

${ }^{4}$ Dollar et al. (2002) examine the effects of standard investment climate variables on firm productivity across states in India and find that less reliable power supply and inferior internet connectivity in poor investment climate states account for a quarter of the TFP differences across states and that a tenth of the differences reflect greater regulatory burden in the same states. Using a more expanded sample of firms which includes Bangladesh, China and Pakistan, Dollar et al. (2005) obtain similar results.
} 


\section{WHY DO EFFECTIVE STATE-BUSINESS RELATIONS MATTER FOR FIRM PERFORMANCE?}

The literature on state-business relations takes the following elements as essential characteristics of effective state-business relations (see Maxfield and Schneider (1997), Chapter 1).

- Transparency: the flow of accurate and reliable information, both ways, between business and government.

- Reciprocity: the capacity and autonomy of state actions to secure improved performance in return for subsidies.

- Credibility: when capitalists are able to believe what state actors say.

Effective SBRs as characterised above can affect firm performance through fulfilling a number of economic functions. Firstly, they can help to solve information related market and co-ordination failures in areas such as skill development or infrastructure provision. For instance, business associations or government departments may coordinate and disperse information among stakeholders.

Secondly, effective SBRs provide a check and balance function on government policies and tax and expenditure plans. Thus, effective SBRs may help to ensure that the provision of infrastructure is appropriate and of good quality. The design of effective government policies and regulations depends, among other things, on input from and consultation with the private sector. Regular sharing of information between the state and businesses ensures that private sector objectives are met with public action and that local level issues are fed into higher level policy processes. The private sector can identify constraints, opportunities, and possible policy options for creating incentives, lowering investment risks, and reducing the cost of doing business. More efficient institutions and rules and regulations might be achieved through policy advocacy which could reduce the costs and risks faced by firms and enhance productivity. 
Finally, effective state-business relations and membership of business association may help to reduce policy uncertainty. Firms operate in an uncertain environment and frequently face risk and resource shortages. They undertake decisions concerning technology, inputs, and production facilities based on anticipated market conditions and profitability. Uncertainty can have significant negative effects on investment, when investment involves large sunk and irreversible costs and there is the option to delay the decision to make the investment until further information becomes available (Dixit and Pindyck 1994). Businesses that have a better relation with government may be able to anticipate policy decisions.

Hisahiro (2005) argues that various forms of information and resources, which are dispersed among entities in the public and private sector, need to be integrated in a more sophisticated way to jointly coordinate policies and provide better public services. It is this combination of insulation and connectedness that minimises the risks and enhances the effectiveness of economic policies. Hence, appropriate government capacity and policy, which is necessary to support private sector development and promote economic growth, can be enabled by good state-business relations and productive public-private sector dialogue.

Thus, effective state-business relations can enhance firm performance by positively affecting the two proximate determinants of firm growth - the rate of factor accumulation and the growth of total factor productivity. Greater transparency in the flow of information between state actors and the business sector leads both to a better allocation of investments by the business sector to their most productive uses and, by reducing policy uncertainty in the minds of investors, a higher rate of investment. Higher credibility of state actions lead to less problems of time and dynamic inconsistency of government policies, providing a more favourable environment for investment to occur. Reciprocity ensures improved performance by private sector actors in return for subsidies and the provision of public goods, contributing to higher productivity growth. 
In summary, effective state-business relations can mitigate both market failures and government failures which are pervasive in most developing countries, and by doing so, bring about an increase in the performance of firms. ${ }^{5}$

\section{MEASURING STATE BUSINESS RELATIONS IN INDIA}

Te Velde (2006) was the pioneering study to develop measures of SBRs quality. He argues that an SBR index should have four components, which reflect the main aspects of effective SBRs:

1) the way in which the private sector is organised vis-à-vis the public sector;

2) the way in which the public sector is organised vis-à-vis the private sector;

3) the practice and institutionalisation of SBRs;

4) the avoidance of harmful collusive behaviour between the two sectors.

Each of the aspects mentioned above is captured through a SBR sub-index which in turn is derived from data on variables reflecting the mentioned aspects. The various SBR sub-indices are then combined to arrive at an overall index of SBR. CMP measure SBR along the above four dimensions for 15 Indian states using both primary and secondary data. We describe below the manner CMP operationalise the measurement of SBR in India.

\section{The role of the private sector in $S B R$}

CMP measure the role of the private sector via the quality and effectiveness of the umbrella business association and two sector based business associations, as follows:

a) Whether the private sector association has a website or not: The variable takes a value of zero in any year in which the organisation does not have a website and 1 otherwise. This is likely to proxy for the quality of the organisational structure as well as its outside visibility. Evidence from their fieldwork

\footnotetext{
${ }^{5}$ See Qureshi and Te Velde 2007 and Sen and Te Velde 2009 for evidence that improvements in state business relations improve economic performance both at the micro and macro levels, for Sub Saharan Africa.
} 
confirms that organisations appearing to be more structured and organised have had an active website in place for a longer time.

b) How frequently the website is updated: Again, this captures the efficiency of internal processes (which makes frequent updates possible) as well as the level of activity of the organisation. The need for updating the website more frequently should increase with the intensity of the organisation's activity.

c) The variable office_premise, takes the value of 1 if the office is owned and 0 otherwise. This variable proxies the level of the organisation's resources as well as the extent to which the association is willing to invest in costly physical assets.

The role of the public sector in SBR

CMP measure the role of the public sector in SBR by the presence of state owned or state participated productive corporations, which are investment promotion agencies, Financial, Infrastructure Development and Tourism Development Corporations. These represent important types of pro-business engagements with benefits for all sectors. They construct a cumulative subindex ranging in value between 0 and 1 which is the average of four dummy variables, one for each organisation. At any point of time the dummy for an organisation takes the value of 1 if it is in place and 0 otherwise.

CMP also assess the role of the public sector via the governments' signalling of their relative priorities through the allocation of public resources. In their work, they focus on two types of state revenue expenditures: expenditure on economic services as a ratio of total government expenditures and expenditure on industries as a ratio of total expenditures on economic services.

\section{The interaction between states and businesses}


CMP measure the interaction between state governments and the business sector in two ways::

\section{a) Index of labour regulation:}

This is the index constructed by Besley and Burgess (2004). The authors score each state level act on labour regulation as anti-worker (assigning -1), pro-worker (1) or neutral (0). In this way they produce a yearly cumulative index which may proxy for the relative effectiveness of the mentioned aspect of SBR. The argument is that more effective SBRs would allow employers to be more influential affecting on government policies and would get reflected in more pro-employer labour market regulation.

\section{b) Stamp Duty:}

As a measure of distortionary taxation at the state level, we use the level of stamp duty over time.

\section{Mechanisms to avoid collusive behaviour}

CMP use the following measures to capture the transparency of SBRs:

a) The gross output of firms belonging to delicensed industries as a proportion of total industrial GDP (data on delicensing from Aghion et al., 2006; data on firms by sector in the Annual Survey of Industries): The License Raj was a system of centralised controls regulating entry and production activity. Delicensing introduced competition and reduced rent-seeking by corporations entrenched with public powers. As the decision of what industries to delicense was made at the central level, this effectively provides an exogenous source of change in the possible extent of collusive behaviour at the state level.

b) Whether the private sector umbrella association has a regular publication informing its members. This measure proxies for the transparency of the organisation's activities. Higher transparency would be associated with lower probability of collusive behaviour which may harm business not entrenched with public authorities. As in the case of the organisation's website, the 
frequency with which the publication is produced and distributed would also determine the level of transparency in the association's activities.

As CMP correctly argue, the indices constructed through these variables have two main advantages over the traditional investment climate indicators. First, they cover a larger time span than any other indicators on India states. This allows one to examine the evolution of the relevant economic institution over different periods. Second, by not being based on firms' perceptions, they avoid the measurement error problem typical of subjective survey response data. Bertrand and Mullainathan (2001) argue that the likely causal correlation of this measurement error with dependent variables may generate biased estimated coefficients. Carlin et al. (2006) explain along these lines the problem of interpreting the coefficients of standard cross-country regressions where a productivity or income measure is regressed on subjective constraints.

To capture indicators of all four dimensions of the composite SBR index (Private Sector, Public Sector, SBR Practice, and anti-collusive behaviour), CMP conducted structured and semi-structured interviews with business associations in each state and state government officials from the industry department of almost every state. Some data was also collected from secondary sources. The data used in the construction of SBR index was a time series for 16 states of India for $1975-2008^{6}$.

There are three separate weighting processes involved in the construction of the SBR index. First, those private sector variables for which data are available for the mentioned three associations in each state need to be weighted to generate an aggregate private sector variable. CMP have experimented with different types of weights to limit the degree of subjectivity in this weighting decision, thus effectively generating different variants of the variables. While CMP used different weighting procedures in the construction of the SBR private variable, we use the weighting procedure where the apex business association is assigned a value of 0.5 and the two sectoral associations are assigned a value of 0.25 each. $^{7}$

\footnotetext{
${ }^{6}$ As the firm level data used in the paper merges the data for Uttarakhand with Uttar Pradesh, we have done the similar exercise for the SBR index. It should be noted that the firm level data is only available for 2000-01 and 2004-05.

${ }^{7}$ We have experimented with different weights for the apex and the two sectoral business associations in the construction of the SBR private variable with no change in the results.
} 
In Figure 1, we present the period averaged SBR measures for 1994-2000 and 20012005. As is clear, there are strong differences in the effectiveness of state business relations across Indian states. These differences seem to have persisted over time.

Figure 1: State Business Relations, 1994-2000 and 2001-2005 across Indian states

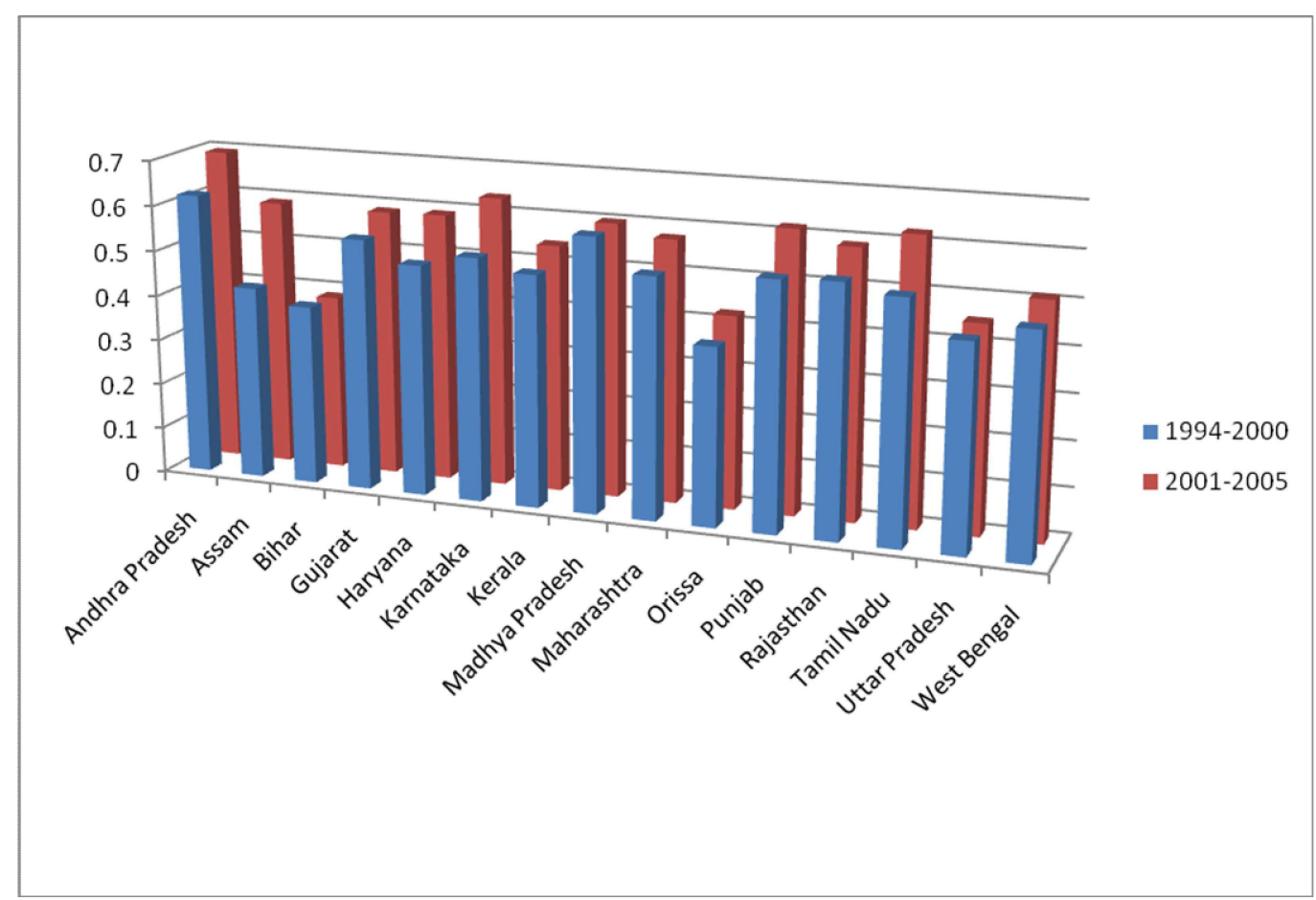

Source: CMP (2009)

\section{DATA AND METHODOLOGY}

Data:

We use unit level data for the formal manufacturing sectors for two years - 2000-01 and 2004-05. Data are drawn from the Annual Survey of Industries (ASI) published by the Central Statistical Organisation (CSO). The ASI is the census survey of all the formal manufacturing units for all the industries across all the states. The data is collected every year from all the units registered under the Indian Factories Act of 1948. ${ }^{8} \mathrm{CSO}$ is the agency that collects information on various aspects of the functioning units. The information collected include - gross output, number of

\footnotetext{
${ }^{8}$ The enterprises which employ less than 20 workers without the use of electricity or 10 workers with the use of the use of electricity or are not producing hazardous substances (such as chemicals) fall under the unorganized/informal sector, as these are firms that are not required to register with the authorities under the Indian Factories Act of 1948.
} 
workers, gross fixed assets, electricity and materials consumed, ownership, profit etc. at the unit level. The data are in the form of repeated cross-sections, and not panel data. This is because the CSO do not reveal the identity of the firm/plant in the unit record data.

\section{Methodology}

Our variable of interest is the measure of state-business relations that we described in Section III and its effect on total factor productivity (TFP). To test the effect of SBR on TFP, we run augmented production functions as follows:

$Y_{i s j}=a_{0}+a_{1} K_{i s j}+a_{2} L_{i s j}+a_{3} S B R_{s}+\partial_{i}+e_{i s j}$

Where $\mathrm{i}$ is industry, $\mathrm{s}$ is state and $\mathrm{j}$ is firm.

$\mathrm{Y}$ is gross value added, $\mathrm{K}$ is capital stock, $\mathrm{L}$ is total number of employees, SBR is our measure of state business relations, $\delta_{\mathrm{i}}$ are industry fixed effects and $\mathrm{e}$ is the error term.

We would expect that $\mathrm{a}_{3}$ is positive and significant - i.e., more effective SBR (as captured by higher SBR score) should lead to improved total factor productivity.

The industry fixed effects capture industry-specific differences in technology which would be correlated with TFP. They also capture other industry specific differences which would affect TFP such as differences in market structure and trade orientation. We first estimate equation (1) using Ordinary Least Squares, and with robust heteroskedasticity constant standard errors. However, it is possible that unobserved technology shocks may be correlated with both, capital stock and output, leading to a bias in estimate of $\mathrm{a}_{1}$. In order to correct for this, we also estimate equation (1) using two-stage least squares with materials as an instrument for capital stock. 


\section{RESULTS}

Table 1 summarises the descriptive statistics of the two years - 2000-01 and 2004-05. For the 2000-01 round, we have data on over 24000 firms. For the 2004-05 round, we have data on over 30000 firms. ${ }^{9}$ There is variation in value added, capital stock and employment for the firms in our sample for both years. We also observe that the summary statistics on value added, capital stock, employment, fuel and materials are not very different for the two years. The SBR public and SBR practice variables have remained more or less same, while the SBR private variable reported a significant improvement over the period 1994-95 - 2000-01.

Table 1. Summary Statistics

\begin{tabular}{|l|c|c|c|c|c|}
\hline VARIABLES & $\begin{array}{c}\text { No. of } \\
\text { Observations }\end{array}$ & Mean & SD & MIN & MAX \\
\hline 2000-20001 ROUND & 24361 & 14.72 & 2.21 & 0.62 & 24.00 \\
\hline Log GVA & 24361 & 14.76 & 2.72 & -0.25 & 24.75 \\
\hline $\begin{array}{l}\text { Log Capital } \\
\text { Stock }\end{array}$ & 24361 & 3.88 & 1.55 & 0 & 10.63 \\
\hline $\begin{array}{l}\text { Log } \\
\text { Employment }\end{array}$ & 24361 & 13.00 & 2.34 & 3.44 & 22.24 \\
\hline Log Fuel & 24361 & 15.31 & 2.93 & 1.96 & 24.88 \\
\hline Log Material & 24361 & 0.177 & 0.017 & 0.135 & 0.210 \\
\hline Log SBR & 24361 & 0.123 & 0.025 & 0.067 & 0.168 \\
\hline Log SBRpvt & 24361 & 0.194 & 0.024 & 0.124 & 0.233 \\
\hline Log SBRpub & 24361 & 0.195 & 0.030 & 0.111 & 0.236 \\
\hline Log SBRpract & 24361 & 0.200 & 0.034 & 0.105 & 0.264 \\
\hline Log SBRcollu & \multicolumn{5}{|l|}{} \\
\hline 2004-2005 Round & 31014 & 14.70 & 2.17 & 2.83 & 24.25 \\
\hline Log GVA & 31014 & 14.68 & 2.67 & -0.42 & 25.66 \\
\hline $\begin{array}{l}\text { Log Capital } \\
\text { Stock }\end{array}$ & 31014 & 3.79 & 1.51 & 0 & 10.73 \\
\hline $\begin{array}{l}\text { Log } \\
\text { Employment }\end{array}$ & 31014 & 12.84 & 2.28 & 3.29 & 22.34 \\
\hline Log Fuel & 31014 & 15.29 & 2.99 & 2.08 & 26.45 \\
\hline Log Material & 31014 & 0.188 & 0.020 & 0.132 & 0.225 \\
\hline Log SBR & 31014 & 0.161 & 0.044 & 0.067 & 0.245 \\
\hline Log SBRpvt & 31014 & 0.195 & 0.025 & 0.107 & 0.231 \\
\hline Log SBRpub & 31014 & 0.196 & 0.027 & 0.128 & 0.236 \\
\hline Log SBRpract & 31014 & 0.215 & 0.026 & 0.133 & 0.252 \\
\hline Log SBRcollu & & & &
\end{tabular}

\footnotetext{
${ }^{9}$ We drop all firms with zero or negative employment or output or capital stock.
} 
Table 2 presents the regression results for the years 2000-01 and 2004-05 obtained using both OLS and IV estimation. In Col. (2) and (3), we present the OLS estimates for the years 2000-01 and 2004-05. The coefficients on labour and capital inputs have the expected signs and are statistically significant at the one per cent level. We find that the coefficient on the SBR measure is positive and significant in all the cases. In Col. (4) and (5), we include industry dummies with no significant change in the results. To correct for the possible endogeneity bias associated with production function estimation, we estimate the equation using instrumental variable (IV) method. The results of this IV exercise with industry dummies are reported in Col. (6) and (7). We find that the coefficient on the SBR variable is positive but not significant for the year 2000-01 while the coefficient value remained significant for the year 2004-05.

In Table 3, we re-do the IV analysis for the different components of our SBR measure. We want to examine whether our finding is driven by specific dimension of SBR measure. We find that SBR private and practice components have a positive and significant effect on TFP for 2004-05. We also find SBR collusive component has a similar effect on TFP but for 2000-01. However, SBR public seems to have a negative and significant effect on TFP for the year 2000-01. This latter finding may possibly reflect the fact that setting up of corporations by the state and public expenditure on economic sectors has not led to the provision of high quality public goods that matter for private sector performance. Nevertheless, it is clear that SBR private, practice and collusive dimensions of the overall SBR measure have contributed to the overall positive impact of effective SBR on firm performance. 
Table 2. Regression Results, OLS and IV

\begin{tabular}{|l|c|c|c|c|c|c|}
\hline Variables & \multicolumn{4}{|c|}{ OLS Estimates } & \multicolumn{2}{|c|}{ IV estimates } \\
\cline { 2 - 7 } & $2000-01$ & $2004-05$ & $2000-01$ & $2004-05$ & $2000-01$ & $2004-05$ \\
\hline Constant & $\begin{array}{c}6.21^{*} \\
(67.92)\end{array}$ & $\begin{array}{c}6.25^{*} \\
(82.44)\end{array}$ & -- & -- & -- & -- \\
\hline Log Capital Stock & $\begin{array}{c}0.354^{*} \\
(65.99)\end{array}$ & $\begin{array}{c}0.35^{*} \\
(73.90)\end{array}$ & $\begin{array}{c}0.32^{*} \\
(54.18)\end{array}$ & $\begin{array}{c}0.31^{*} \\
(62.05)\end{array}$ & $\begin{array}{c}0.71^{*} \\
(72.89)\end{array}$ & $\begin{array}{c}0.65^{*} \\
(81.56)\end{array}$ \\
\hline Log Employment & $\begin{array}{c}0.767^{*} \\
(102.01)\end{array}$ & $\begin{array}{c}0.79^{*} \\
(123.11)\end{array}$ & $\begin{array}{c}0.83^{*} \\
(99.33)\end{array}$ & $\begin{array}{c}0.85^{*} \\
(126.10)\end{array}$ & $\begin{array}{c}0.33^{*} \\
(25.25)\end{array}$ & $\begin{array}{c}0.42^{*} \\
(39.30)\end{array}$ \\
\hline Log SBR & $\begin{array}{c}1.782^{*} \\
(4.33)\end{array}$ & $\begin{array}{c}1.66^{*} \\
(5.59)\end{array}$ & $\begin{array}{c}1.12^{*} \\
(2.79)\end{array}$ & $\begin{array}{c}2.28^{*} \\
(8.35)\end{array}$ & $\begin{array}{c}0.45 \\
(0.93)\end{array}$ & $\begin{array}{c}1.37^{*} \\
(4.30)\end{array}$ \\
\hline Industry & No & No & Yes & Yes & Yes & Yes \\
Dummies? & 0.81 & 0.82 & 0.83 & 0.85 & 0.74 & 0.78 \\
\hline R-square & 24361 & 31014 & 24361 & 31014 & 24361 & 31014 \\
\hline $\begin{array}{l}\text { Number of } \\
\text { Observations }\end{array}$ & & & & & \\
\hline
\end{tabular}

Note: t-values are in the parentheses.

Table 3. IV estimates: SBR Components

\begin{tabular}{|l|c|c|c|c|c|c|c|c|}
\hline Variables & \multicolumn{2}{|c|}{ SBR Private } & \multicolumn{2}{l|}{ SBR Public } & \multicolumn{2}{l|}{ SBR Practice } & \multicolumn{2}{l|}{ SBR Collusive } \\
\hline $\begin{array}{l}\text { Log Capital } \\
\text { Stock }\end{array}$ & $\begin{array}{c}0.71^{*} \\
(71.49)\end{array}$ & $\begin{array}{c}0.65^{*} \\
(80.60)\end{array}$ & $\begin{array}{c}0.71^{*} \\
(72.68)\end{array}$ & $\begin{array}{c}0.65^{*} \\
(81.34)\end{array}$ & $\begin{array}{c}0.71^{*} \\
(72.78)\end{array}$ & $\begin{array}{c}0.65^{*} \\
(80.91)\end{array}$ & $\begin{array}{c}0.71^{*} \\
(72.35)\end{array}$ & $\begin{array}{c}0.65^{*} \\
(80.76)\end{array}$ \\
\hline $\begin{array}{l}\text { Log } \\
\text { Employment }\end{array}$ & $\begin{array}{c}0.33^{*} \\
(25.09)\end{array}$ & $\begin{array}{c}0.43^{*} \\
(39.53)\end{array}$ & $\begin{array}{c}0.34^{*} \\
(25.28)\end{array}$ & $\begin{array}{c}0.42^{*} \\
(39.46)\end{array}$ & $\begin{array}{c}0.33^{*} \\
(25.23)\end{array}$ & $\begin{array}{c}0.42^{*} \\
(38.88)\end{array}$ & $\begin{array}{c}0.33^{*} \\
(24.75)\end{array}$ & $\begin{array}{c}0.43^{*} \\
(39.28)\end{array}$ \\
\hline Log SBR & $\begin{array}{c}0.43 \\
(1.39)\end{array}$ & $\begin{array}{c}1.02^{*} \\
(7.27)\end{array}$ & $\begin{array}{c}-0.67^{*} \\
(2.09)\end{array}$ & $\begin{array}{c}-0.24 \\
(0.98)\end{array}$ & $\begin{array}{c}0.07 \\
(0.27)\end{array}$ & $\begin{array}{c}0.65^{*} \\
(2.88)\end{array}$ & $\begin{array}{c}0.86^{*} \\
(3.89)\end{array}$ & $\begin{array}{c}-0.32 \\
(1.36)\end{array}$ \\
\hline $\begin{array}{l}\text { Industry } \\
\text { Dummies? }\end{array}$ & Yes & Yes & Yes & Yes & Yes & Yes & Yes & Yes \\
\hline R-square & 0.74 & 0.78 & 0.74 & 0.78 & 0.74 & 0.78 & 0.74 & 0.78 \\
\hline $\begin{array}{l}\text { Number of } \\
\text { Observations }\end{array}$ & 24361 & 31014 & 24361 & 31014 & 24361 & 31014 & 24361 & 31014 \\
\hline
\end{tabular}

\section{CONCLUSIONS}

It is commonly argued that a better investment climate reform - that is, lower distortions in the institutional, policy and regulatory environment in which firms operate - lead to discernible improvements in firm performance. In this paper, we argue that effective state business relations condition better investment climate outcomes and that the deeper institutional determinants of firm performance are the former. We examine the effect of effective state-business relations of total factor productivity (TFP) for formal manufacturing sector firms in India for the years 199495 and 2000-01, and find support for this hypothesis. We find a positive effect of state-business relations on TFP of the formal manufacturing sector. 
Our disaggregated analysis of which dimension of SBR matter most for firm performance suggest that the SBR private, practice and collusive components contribute to the overall impact of effective SBR on firm performance. However, SBR public seems to have a negative effect on TFP. Thus our results suggest that it is important to improve the quality of public goods provided by the sub-national state governments which can further enhance the impact of other sub-components. Overall, our finding suggests that collaborative relationships between the state and the business sector can be performance enhancing and the goal of policy should be to strengthen such relationships. 


\section{REFERENCES:}

Amsden, A. 1989. Asia's Next Giant: South Korea and Late Industrialisation, New York, Oxford University Press

Cali, M., Mitra, S. and Purohit, P. 2009. 'State-Business Relations in Indian states: Paper towards constructing an effective SBR index for Indian states', Discussion Paper No. 25, IPPG: Manchester

Carlin, W. and Seabright, P. 2009. 'Bring Me Sunshine: Which Parts of the Business Climate Should Public Policy Try to Fix?', in J. Lin and Pleskovic, B. (eds) Annual Bank Conference on Development Economics: Private Sector and Development. Washington D.C., World Bank

Commander, S. and K. Trinn (2008), 'Explaining the performance of countries and firms: what role does the business environment play?, London Business School, mimeo.

Dethier, J-J., Hirn, M. and Straub, S. 2008. 'Explaining Enterprise Performance in Developing Countries with Business Climate Survey Data', Policy Research Working Paper No. 4792, World Bank

Dixit, A. and R. Pindyck 1994. Investment under Uncertainty, Princeton, Princeton University Press

Dollar, D., Iarossi, G. and Mengistae, T. 2002. 'Investment Climate and Economic Performance: Some Firm Level Evidence from India', Working Paper No. 143, Centre for Research on Economic Development and Policy Reform, Stanford University

Dollar, D., Hallward-Driemeier, M. and Mengistae, T. 2005. Investment Climate and Firm Performance in Developing Countries, Economic Development and Cultural Change, Vol. 54, No.1, 1-31

Doner, R.F and Schneider, M.R. 2000. Business Associations and Economic Development: Why Some Associations Contribute More than Others, Business and Politics, Vol. 2, No. 3, 261-288

Evans, P. 1995. Embedded Autonomy: States and Industrial Transformation. Princeton, Princeton University Press

Harriss, J. 2006. 'Institutions and State-Business Relations', Briefing Note 2, IPPG: London.

Hisahiro, K. 2005. 'Comparative Analysis of Governance: Relationship between Bureaucracy and Policy Co-ordination Capacity with Particular Reference to Bangladesh', Institute for International Cooperation

Hyden, G. J. Court and Maese, K.2004. Making Sense of Governance: Empirical Evidence from Sixteen Developing Countries, Boulder, Co: Lynne Rienner 
Maxfield, S. and B.R. Schneider 1997. Business and the State in Developing Countries, Ithaca., Cornell University Press

Moore, M. and Schmitz, H. 2008. 'Idealism, Realism and the Investment Climate in Developing Countries', Working Paper No. 307, Institute of Development Studies.

Qureshi, M. and te Velde, D.W. 2007. 'State-Business Relations and Firm Performance in Zambia', Discussion Paper No. 5, IPPG: London

Sen, K. and te Velde, D. W. 2009. State Business Relations and Economic Growth in Sub-Saharan Africa, Journal of Development Studies, Vol. 45, No. 8, 1-17

Steer, L. and Sen, K. 2009. 'Informal Institutions in Transition: How the Private Sector Boomed without Legal Protection in Vietnam', Discussion Paper No. 19, IPPG: Manchester

te Velde, D.W. 2006. 'Measuring State Business Relations in Sub-Saharan Africa', Discussion Paper No. 4, IPPG: London

Veeramani, C. and B. Goldar (2004). 'Investment Climate and Total Factor Productivity in Mnaufactuirng: Analysis of Indian States', Working paper No. 127, ICRIER: New Delhi.

World Bank 2004. 'India Investment Climate Assessment 2004: Improving Manufacturing Competitiveness', Washington D C; The World Bank. 